\title{
ANALISIS VALUE CHAIN DALAM UPAYA PENINGKATAN COMPETITIVE ADVANTAGE
}

\author{
Ratna Christiana Dewi ${ }^{a}$ \\ Basuki $^{\text {b }}$ \\ ${ }^{a}$ Sekolah Pascasarjana Universitas Airlangga ${ }^{b}$ Fakultas Ekonomi dan Bisnis Universitas Airlangga \\ Email: ratna.christina.dewi@gmail.com ${ }^{a}$; basuki@feb.unair.ac.id ${ }^{b}$
}

\section{ARTICLE HISTORY}

Received:

3 August 2017

Revised

29 August 2017

Accepted:

13 September 2017

Online available:

9 November 2017

Keywords :

Analisis value chain, competitive

advantage, strategi cost leadership

*Correspondence:

Name:

E-mail: ........

\section{ABSTRACT}

Introduction: This study aims to identify primary activities in the value chain analysis process to increase competitive advantage (competitive advantage) in order to support the cost leadership strategy of East Java Youth Lodging in order to survive and win with other tourist lodges and inns in Surabaya.

Methods: This research uses a qualitative approach with the method chosen is a case study, while the type of this research is exploratory research.

Results: The result of this research is that East Java Youth Lodging still has the opportunity to develop and compete in facing business threats because the Youth Lodging currently has a cost leadership strategy. East Java Youth Lodging as one of the accommodation services that offers cheaper prices with services and facilities that are no less than tourist lodges and other inns in Surabaya.

Conclusion: Through the indication of primary activities with the value chain analysis process identified cost drivers that create opportunities for cost reduction, especially in logistics, so that the reduction in costs can be used as an increase in competitive advantage for East Java Youth Lodging. 


\begin{abstract}
Abstrak
Persaingan bisnis dibidang jasa akomodasi khususnya di Surabaya semakin ketat. Persaingan tersebut menyebabkan masing-masing jasa akomodasi berusaha memberikan pelayanan dan fasilitas semaksimal mungkin. Pondok Wisata dan Penginapan sebagai salah satu usaha akomodasi juga dituntut untuk lebih meningkatkan kualitas pelayanan yang diberikan dan strategi bisnisnya, termasuk Penginapan Remaja Jawa Timur. Penelitian ini bertujuan mengidentifikasi aktivitas-aktivitas primer dalam proses analisis value chain untuk peningkatan competitive advantage (keunggulan bersaing) dalam rangka mendukung strategi cost leadership pada Penginapan Remaja Jawa Timur agar dapat bertahan dan menang dengan pondok wisata dan penginapan lainnya di Surabaya. Penelitian ini menggunakan pendekatan kualitatif dengan metode yang dipilih adalah studi kasus, adapun jenis penelitian ini adalah exploratory research.

Hasil dari penelitian ini yaitu Penginapan Remaja Jawa Timur masih berpeluang untuk berkembang dan bersaing meskipun menghadapi ancaman bisnis karena Penginapan Remaja saat ini memiliki strategi cost leadership. Penginapan Remaja Jawa Timur sebagai salah satu jasa akomodasi menawarkan harga yang lebih murah dengan pelayanan dan fasilitas yang tidak kalah dibandingkan pondok wisata dan penginapan lainnya di Surabaya. Melalui identifikasi aktivitas-aktivitas primer dengan proses analisis value chain teridentifikasi cost driver yang menciptakan peluang bagi penurunan biaya terutama pada logistik dalam sehingga dengan penurunan biaya tersebut dapat dijadikan sebagai peningkatan competitive advantage bagi Penginapan Remaja Jawa Timur.
\end{abstract}

\title{
INTRODUCTION
}

Didalam industri akomodasi, hotel bukanlah satu-satunya bentuk usaha jasa akomodasi. Tetapi masih ada beberapa akomodasi lain, hal ini sesuai Peraturan Menteri Kebudayaan dan Pariwisata Nomor : PM.86/HK.501/MKP/2010 Tahun 2010 Tentang Tata Cara Pendaftaran Usaha Penyediaan Akomodasi Pasal 4 dan Peraturan Daerah Kota Surabaya Nomor : 23 Tahun 2012 Tentang Kepariwisataan.

Perkembangan jumlah industri jasa akomodasi tahun 2010 - 2012 di Provinsi Jawa Timur yang terdiri dari hotel bintang, hotel melati, pondok wisata dan penginapan dapat dilihat pada tabel 1. Hotel bintang di Jawa Timur hanya tersebar di 12 Kabupaten/Kota dimana sejumlah 32 hotel bintang berlokasi di Surabaya, sedangkan hotel melati lokasinya menyebar di seluruh wilayah di Jawa Timur terutama Kabupaten/Kota yang mempunyai daya tarik cukup besar, baik sebagai daerah tujuan wisata maupun pusat bisnis. 
Tabel 1

Jumlah Industri Jasa Akomodasi di Jawa Timur Tahun 2010 - 2012

\begin{tabular}{cccccccc}
\hline \multirow{2}{*}{ No } & \multirow{2}{*}{ Jenis Akomodasi } & \multicolumn{2}{c}{$\mathbf{2 0 1 0}$} & \multicolumn{2}{c}{$\mathbf{2 0 1 1}$} & \multicolumn{2}{c}{2012} \\
\cline { 3 - 7 } & & Unit & Kamar & Unit & Kamar & Unit & Kamar \\
\hline 1 & Hotel Bintang & 71 & 8.841 & 71 & 8.841 & 75 & 8.927 \\
2 & Hotel Melati & 786 & 20.237 & 799 & 20.312 & 776 & 19.789 \\
3 & Pondok Wisata \& Penginapan & 418 & 1.929 & 418 & 1.929 & 418 & 1.929 \\
\hline & Total & 1.275 & 31.007 & 1.288 & 31.082 & 1.309 & 30.645 \\
\hline
\end{tabular}

Sumber : Disbudapar Provinsi Jatim

Persaingan bisnis dibidang jasa akomodasi khususnya di Surabaya semakin ketat. Persaingan yang ketat tersebut menyebabkan masing-masing jasa akomodasi berusaha memberikan pelayanan dan fasilitas semaksimal mungkin. Untuk dapat bertahan dan menang dalam persaingan tersebut, pelaku bisnis pun dituntut untuk lebih meningkatkan kualitas pelayanan yang diberikan dan strategi bisnisnya. Sesuai data Dinas Kebudayaan dan Pariwisata Provinsi Jawa Timur perkembangan wisatawan mancanegara (wisman) yang menginap di akomodasi Jawa Timur pada tahun 2012 mencapai 269.943 orang atau naik 20,34 persen dibandingkan tahun 2011 yang sebesar 224.317 orang. Sedangkan perkembangan wisatawan nusantara (wisnus) yang menginap di akomodasi Jawa Timur pada tahun 2012 mencapai 3.562 .965 orang atau naik 4,26 persen dibandingkan tahun 2011 yang sebesar 3.417.278 orang. Tingkat hunian kamar untuk hotel bintang di Jawa Timur mencapai 44,28\%, hal ini menunjukkan bahwa pada tahun 2012 setiap 100 kamar yang tersedia di hotel bintang pada setiap malamnya ratarata ada 44 hinga 45 kamar yang terjual atau dihuni oleh tamu. Sedangkan tingkat hunian kamar untuk hotel melati di tahun 2012 mencapai 32,77\%.

Penginapan Remaja merupakan milik Dinas Kebudayaan dan Pariwisata Provinsi Jawa Timur yang berfungsi untuk memberikan pelayanan akomodasi alternatif bagi wisatawan atau tamu yang berkunjung di Surabaya. Sebagai jasa akomodasi, Penginapan Remaja yang berlokasi di Jl. Darmo Kali Surabaya ini menyediakan jasa penginapan, makanan, minuman dan jasa lainnya. Dalam menyediakan jasanya Penginapan Remaja harus selalu memperhatikan mulai dari fasilitas hotel, keadaan kamar, harga sewa kamar dan bagaimana pihak hotel melayani konsumen.. Hal ini dilakukan agar para konsumen tetap loyal. Ada banyak hotel dan penginapan lain yang sama-sama berlomba memenangkan persaingan dengan tetap mempertahankan loyalitas konsumen. Persaingan tersebut salah satunya dapat terlihat pada jumlah tamu yang menginap di pondok wisata dan penginapan sebagaimana terlihat pada Tabel 2.

Tabel 2

Jumlah Tamu Menginap di Pondok Wisata \& Penginapan Kota Surabaya Tahun 2012

\begin{tabular}{llll}
\hline No & Nama Usaha & Alamat & 2012 \\
\hline
\end{tabular}

Published by University of Airlangga.

This is an open access article under the CC BY SA license (https://creativecommons.org/licenses/by-sa/4.0/) 


\begin{tabular}{cllc}
\hline 1 & Griyo Nur Pondok Keluarga & Jl. Dukuh Kupang XXX/ 45-47 & 1.393 \\
2 & Pondok Asri Family & Jl. Kalibokor Selatan 108 & 1.528 \\
3 & Nugraha Home Stay & Jl. Kedung Pengkol VI/05 & 1.200 \\
4 & Riyadi Guest House & Jl. Panjangjiwo Permai II/7 & 128 \\
5 & Penginapan Orchid & Jl. Bongkaran 49 & 163 \\
6 & Home Stay Gayungan & Jl. Gayungan 32 & 1.191 \\
7 & Widya Kartika & Jl. Dukuh Kupang Timur XII-120 & 66 \\
8 & Peng.Remaja Jatim & Jl. Darmokali 35 & 1.961 \\
9 & PW. Sagita & Jl. Jemursari Selatan VI/11 & 74 \\
10 & Dinar Home Stay & Jl. Gayungan Kebonsari VII/ 20 & 2.405 \\
\hline
\end{tabular}

Sumber : Disbudpar Kota Surabaya

Sebagai salah satu jasa akomodasi, Penginapan Remaja bertanggung jawab untuk memenuhi harapan masyarakat dan juga pemerintah sebagai pemilik dalam hal ini Dinas Kebudayaan dan Pariwisata Provinsi Jawa Timur. Semua kamar yang ada di Penginapan Remaja ini, bisa digunakan untuk para tamu atau wisatawan yang akan menginap. Di Penginapan Remaja untuk BOR (Bed Occupancy Ratio / angka penggunaan tempat tidur) dimana Jumlah hari menginap / (Jumlah tempat tidur $X$ Jumlah hari dalam satu periode) X $100 \%$ pada tahun 20XX mencapai $69,38 \%$ mengalami kenaikan dibandingkan tahun sebelumnya yang hanya mencapai 60,88\% (Diolah dari sumber Dinas Kebudayaan dan Pariwisata Provinsi Jawa Timur). Dalam menghadapi persaingan yang semangkin ketat Penginapan Remaja perlu menerapkan strategi yang professional agar dapat bersaing dengan jasa akomodasi lainnya.

Salah satu alat analisis manajemen biaya yang dapat digunakan oleh perusahaan untuk membuat keputusan strategis dalam menghadapi persaingan bisnis adalah analisis value chain. Shank dan Govindarajan (1995:34); Porter (2001:12), mendefinisikan Value Chain Analysis, sebagai alat untuk memahami value chain yang membentuk suatu produk. Value chain ini berasal dari aktivitas-aktivitas yang dilakukan, mulai dari bahan baku sampai ke tangan konsumen, termasuk juga pelayanan purna jual.

Dengan demikian analisis value chain dapat digunakan sebagai salah satu alat analisis manajemen biaya untuk pengambilan keputusan strategis dalam menghadapi persaingan bisnis yang semakin ketat. Keputusan ini menentukan strategi kompetitif yang akan diaplikasikan, apakah menggunakan strategi cost leadership atau diferensiasi (Porter, 1985:15), untuk berkompetisi di pasar. Masing-masing strategi tersebut membutuhkan penanganan pengelolaan yang berbeda (Donelan, Kaplan, 2000:43). Strategi cost leadership membutuhkan penekanan pada pemeliharaan/pengelolaan struktur biaya yang lebih rendah dari para pesaing secara signifikan. Hal ini dapat dilakukan dengan membatasi penawaran produk, mengurangi tingkat kerumitan produk, atau pembatasan layanan konsumen. Strategi differensiasi juga membutuhkan usaha 
Ratna Cristiana Dewi

pengendalian biaya secara berkelanjutan, tetapi penekanan strategi manajemen akan 
diarahkan pada differensiasi produk. Hal ini mungkin dapat dilakukan dengan menawarkan penambahan fasilitas (value added) dari produk, meningkatkan line product atau memperluas jaringan layanan konsumen.

Strategi apapun yang dipilih, analisis value chain dapat membantu perusahaan untuk fokus pada rencana strategi yang dipiih dan berusaha untuk meraih keunggulan bersaing. Weiler et al. (2004:21), menyatakan bahwa pendekatan analisis value chain merupakan pendekatan terbaik dalam membangun nilai perusahaan kearah yang lebih baik. Penginapan Remaja Dinas Kebudayaan dan Pariwisata Provinsi Jawa Timur memerlukan pengelolaan aktivitas-aktivitas dalam value chain usahanya guna mendukung penerapan strategi cost leadership terutama penekanan pada aktivitas primer. Hal ini menjadi penting karena melalui analisis value chain akan dapat diidentifikasi aktivitas-aktivitas apa saja yang belum atau yang sudah mampu memberikan nilai keunggulan bersaing perusahaan dimana menurut data internal yang ada, aktivitas primer berkontribusi pada biaya yang terbesar dibandingkan pada aktivitas yang lainnya (Sunardi, 2011).

\section{LITERATURE REVIEW}

\section{The traditional society}

\section{Value Chain Analysis (Analisis Rantai Nilai)}

Shank dan Govindarajan (1993:48); Porter (2001:15), mendefinisikan Value Chain Analysis, merupakan alat untuk memahami rantai nilai yang membentuk produk. Rantai nilai ini berasal dari aktivitas-aktivitas yang dilakukan, mulai dari bahan baku sampai ke tangan konsumen, termasuk juga pelayanan purna jual. Selanjutnya Porter (1985:40) menjelaskan, Analisis value-chain merupakan alat analisis strategik yang digunakan untuk memahami secara lebih baik terhadap keunggulan kompetitif, untuk mengidentifikasikan dimana value pelanggan dapat ditingkatkan atau penurunan biaya, dan untuk memahami secara lebih baik hubungan perusahaan dengan pemasok/supplier, pelanggan dan perusahaan lain dalam industri.

\section{Competitive Advantage (Keunggulan Bersaing)}

Menurut Porter (1985:21), keunggulan bersaing adalah jantung dari kinerja perusahaan di dalam pasar yang bersaing. Keunggulan bersaing adalah mengenai bagaimana sebuah perusahaan benar-benar menerapkan strategi (bersaing) generik yang ada ke dalam praktek bisnisnya. Pada dasarnya keunggulan bersaing berkembang dari nilai yang perusahaan mampu ciptakan untuk pembelinya, misalnya : harga yang lebih rendah dibandingkan harga pesaing untuk manfaat yang sepadan atau penyediaan manfaat unik yang lebih dari sekedar mengimbangi harga premi.

\section{Previous Study}




\section{Ratna Cristiana Dewi}

Penelitian yang dilakukan Sulistijowati (2012) meneliti dengan judul Analisis Value Chain Pada Aktivitas Primer Dengan Penerapan Strategi Cost Leadership Sebagai Upaya Peningkatan Keunggulan Bersaing (Studi Kasus Pada PT. Semen Gresik). Persamaan dengan penelitian ini yaitu sama-sama meneliti kondisi faktual suatu obyek unit usaha untuk perencanaan strategis serta melakukan analisis strategi bersaing yang tepat dalam lingkungan yang dinamis serta lebih spesifik pada satu bagian yaitu aktivitas primer.

Perbedaan dengan penelitian ini unit usaha yang diteliti amat berbeda, yang diteliti pada penelitian Sulistijowati (2012) adalah studi kasus pada PT. Semen Gresik, sedangkan pada penelitian ini dilakukan pada Penginapan Remaja Dinas Kebudayaan dan Pariwisata Provinsi Jawa Timur yang merupakan aset pemerintah Jawa Timur dibidang akomodasi yang tentunya dalam penentuan strategi masih dipengaruhi kuatnya birokarasi sehingga strategi yang diterapkan untuk menghadapi persaingan juga akan berbeda.

\section{RESEARCH METHODS}

Penelitian ini menggunakan pendekatan kualitatif dengan metode yang dipilih adalah studi kasus. Penelitian ini untuk mengidentifikasikan aktivitas-aktivitas primer dalam proses analisis value chain dan melakukan proses analisis value chain pada aktivitas-aktivitas primer untuk peningkatan keunggulan bersaing (competitive advantage) dalam rangka mendukung strategi cost leadership di Penginapan Remaja Dinas Kebudayaan dan Pariwisata Provinsi Jawa Timur. Pengumpulan data dengan melakukan wawancara secara berulang antara peneliti dengan subyek penelitian, dalam hal ini Kepala Dinas / Sekretaris / Kasubag Tata Usaha dan Kepegawaian Dinas Kebudayaan dan Pariwisata Provinsi Jawa Timur, Ketua Koordinator Petugas dan karyawan Penginapan Remaja Dinas Kebudayaan dan Pariwisata Provinsi Jawa Timur. Selain itu, dalam penelitian lapangan ini juga dilakukan dengan observasi atau pengamatan langsung ke Penginapan Remaja Dinas Kebudayaan dan Pariwisata Provinsi Jawa Timur.

\section{RESULT AND ANALYSIS}

Analisis value chain untuk aktivitas primer dari Penginapan Remaja dapat dijabarkan sebagai berikut :

1. Mengumpulkan data yang berkaitan dengan aktivitas primer Penginapan Remaja Data yang dibutuhkan dari rincian biaya dan aktivitas primer penginapan, dilakukan analisis yaitu dengan mengidentifikasi aktivitas nilai dan pengalokasian biaya pada tiap aktivitas value chain yang digunakan untuk mengetahui aktivitas primer yang terjadi dalam penginapan dan mengidentifikasi pemicu biaya dari tiap aktivitas primer 
yang dilakukan serta kemungkinan terdapat penurunan biaya guna mencapai strategi cost leadership.

2. Mengidentifikasi aktivitas-aktivitas penginapan ke dalam value chain

Adapun aktivitas primer tersebut pada Penginapan Remaja dapat diuraikan sebagai berikut :

\section{a.Logistik dalam}

Aktivitas ini merupakan aktivitas yang berhubungan dengan penerimaan dan pengendalian produk. Aktivitas logistik dalam yang dilakukan Penginapan Remaja meliputi aktivitas penerimaan bahan baku makanan dan minuman, serta produkproduk-produk fasilitas penginapan seperti sikat gigi, sabun mandi, shampoo, handuk, dan lain-lain serta melakukan pengendalian terhadap produk-produk tersebut.

Aktivitas-aktivitas yang termasuk dalam logistik dalam antara lain :

- Urusan administrasi dan keamanan penginapan mencatat kebutuhan perlengkapan penginapan sesuai dengan kegiatan penginapan dan membuat permintaan barang berdasarkan kebutuhan dilapangan baik dari hasil kesepakatan rapat ataupun kebutuhan mendadak yang ditujukan kepada Kepala Sub. Bagian Tata Usaha dan Kepegawaian Dinas Kebudayaan dan Pariwisata Provinsi Jawa Timur, dimana anggaran Penginapan Remaja masuk dalam Sub. Bagian Tata Usaha dan Kepegawaian. Untuk pengadaan logistik dalam setiap tahunnya ditambah $10 \%$ - 15\% dari jumlah hari pemakaian kamar, dengan pertimbangan melihat prosentase kenaikan tingkat hunian kamar setiap tahunnya sekitar 10\% - 15\%.

- Bagian pengadaan barang dalam hal ini Sub. Bagian Tata Usaha dan Kepegawaian menerima permintaan kebutuhan perlengkapan yang diajukan oleh penginapan tersebut dilakukan evaluasi dan pengecekan serta menerbitkan dokumen permintaan barang tersebut.

- Dokumen permintaan barang yang telah diterbitkan diajukan ke Kepala Dinas Kebudayaan dan Pariwisata Provinsi Jawa Timur untuk dimintakan persetujuan.

- Dokumen yang telah disetujui Kepala Dinas, dicatat oleh bagian pengadaan barang dan melakukan rekapitulasi harga setelah dibelikan di toko atau supermarket yang menyediakan barang tersebut.

- Setelah barang dibeli, pihak urusan administrasi penginapan mengambil barang ke Dinas Kebudayaan dan Pariwisata Provinsi Jawa Timur.

Kekuatan-kekuatan yang dapat diidentifikasi dalam aktivitas logistik dalam adalah :

- Perencanaan yang matang dari Urusan Administrasi dan Keamanan, sehingga kebutuhan untuk logistik dalam di Penginapan Remaja bisa dipersiapkan dengan baik. 


\section{Ratna Cristiana Dewi}

- Koordinasi antara Urusan Administrasi dan Keamanan, Urusan Kantor Depan, Urusan Tata Graha dan Urusan Tata Boga sudah berjalan dengan baik.

- Tidak tergantung secara berlebihan terhadap produk tertentu secara khusus terkait kebutuhan logistik dalam Penginapan Remaja.

Berkaitan dengan penghematan biaya logistik dalam di Penginapan Remaja kelemahannya tidak bekerjasama atau melakukan kontrak dengan supplier yang menyediakan terkait logistik dalam tersebut dan tidak ada peraturan jika ada barang yang hilang pada saat tamu menginap di penginapan harus di charge atau dikenakan denda atas kehilangan barang tersebut (misalnya handuk, asbak, hanger, dll).

b.Operasi

Aktivitas ini berupa kegiatan operasional pada Penginapan Remaja yaitu melakukan penjualan produk-produk berupa kamar hotel, ruang pertemuan/aula dan berbagai fasilitas lain yang tersedia.

Di dalam kegiatan operasional ini dapat diidentifikasikan kekuatan-kekuatan sebagai keunggulan bersaing bagi Penginapan Remaja antara lain :

- Memiliki area parkir yang luas

- Disetiap lantai memiliki lobby yang luas sehingga jika ada tamu rombongan bisa berkumpul, bersendau gurau dan santai di lobby tersebut

- Meskipun kamar yang disediakan Penginapan Remaja hanya standar, namun fasilitas yang diberikan tidak kalah dengan hotel-hotel melati yang menyediakan berbagai macam tipe kamar. Fasilitas tersebut antara lain ada AC, twinbeed dan doublebed, kamar mandi dalam dan TV

- Memiliki ruang meeting/aula yang ber-AC, sound system, meja kursi, white board dan layar proyektor. Fasilitas ruang meeting/aula tersebut juga tidak kalah dengan ruang meeting/aula yang disediakan oleh hotel-hotel melati lainnya.

- Dengan fasilitas dan pelayanan yang setaraf pondok wisata dan penginapan lain di Surabaya, Penginapan Remaja memiliki tarif kamar yang lebih murah seperti terlihat dalam tabel 5.3.

Tabel 3

Daftar Tarif Kamar Pondok Wisata dan Penginapan Lain Kota Surabaya

\begin{tabular}{|c|c|c|}
\hline Nama Usaha & Alamat & Tarif/Kamar (Rp.) \\
\hline 1. Pondok Asri Family & Jl. Kalibokor Selatan 108 & $210.000,00$ \\
\hline 2. Nugraha Home Stay & Jl. Kedung Pengkol VI/05 & $190.000,00$ \\
\hline 3. Riyadi Guest House & Jl. Panjangjiwo Permai II/7 & $209.000,00$ \\
\hline 4. Penginapan Orchid & Jl. Bongkaran 49 & $180.900,00$ \\
\hline 5. Home Stay Gayungan & Jl. Gayungan 32 & $175.000,00$ \\
\hline 6. Penginapan Remaja Jatim & Jl. Darmokali 35 & $165.000,00$ \\
\hline 7. Dinar Home Stay & Jl. Gayungan Kebonsari VII/20 & $250.000,00$ \\
\hline
\end{tabular}

Sumber : Disbudpar Kota Surabaya (20XX)

Published by University of Airlangga.

This is an open access article under the CC BY SA license (https://creativecommons.org/licenses/by-sa/4.0/) 
Selain itu juga masih terdapat kelemahan-kelemahan yang dapat mengurangi keunggulan bersaing bagi Penginapan Remaja yaitu : ada sekitar 3 kamar yang masih menggunakan karpet lama sehingga terlihat kurang bersih dan rapi.

\section{c.Pemasaran dan Penjualan}

Aktivitas pemasaran dan penjualan dilakukan oleh Penginapan Remaja untuk menarik minat pelanggan terhadap produk-produk yang dipasarkan. Kegiatan pemasaran dan penjualan yang dilakukan adalah dengan mengadakan kerjasama dengan biro perjalanan, masuk menjadi anggota Asosiasi Pondok Pemuda Indonesia (APPI) dan International Youth Hostel Federation (IYHF), penyebaran brosur ke Perguruan Tinggi Negeri dan Swasta, serta menjalin hubungan yang baik dengan semua wisma yang ada di Surabaya.

Berkaitan dengan aktivitas pemasaran dan penjualan Penginapan Remaja, berdasarkan pengamatan, wawancara di lapangan dan analisa dokumen yang ada, memiliki kelebihan-kelebihan sebagai berikut :

- Memiliki pangsa pasar yang kuat dalam pemerintahan dan kelompok/ group

- Akomodasi seperti hostelling/pondok/ penginapan juga terkena akses dari yang disebut era globalisasi. Oleh karena itu Penginapan Remaja sebagai bagian dari usaha akomodasi tesebut tidak ingin tertinggal dan ingin mengembangkan keberadaannya di masyarakat luas bergabung dengan Asosiasi Pondok Pemuda Indonesia (APPI) dan International Youth Hostel Federation (IYHF)

- Bekerja sama dengan biro perjalanan sehingga dapat membantu Penginapan Remaja untuk meningkatkan penjualan, karena biasanya para tamu lebih memilih untuk memesan kamar dari biro perjalanan.

- Masih memiliki potensi untuk pengembangan fisik gedung dan fasilitas lain dalam rangka mengembangkan bisnisnya serta pembenahan dan pemeliharaan fisik gedung secara rutin yang dananya direncanakan dan direalisasikan dengan dana proyek APBD Provinsi Jawa Timur

- Penginapan Remaja terletak di dekat pusat perbelanjaan dan perkantoran.

Adapun kelemahan-kelemahan terkait aktivitas pemasaran dan penjualan pada

Penginapan Remaja sebagai berikut :

- Bukan merupakan akomodasi yang memiliki cabang di luar Jawa Timur sehingga Penginapan Remaja tidak dikenal dengan baik oleh seluruh masyarakat di Indonesia

- Tidak memiliki brand penginapan yang kuat secara luas

- Kurangnya melakukan kegiatan pemasaran.

d.Pelayanan Purna Jual 


\section{Ratna Cristiana Dewi}

Kekuatan yang dapat diidentifikasikan dalam aktivitas pelayanan purna jual Penginapan Remaja yaitu semua karyawan/karyawati secara berkala dilatih untuk meningkatkan kemampuan dan pengetahuan terkait standar pelayanan dalam penanganan tamu mulai dari check in, check out dan pembayaran serta mengakomodasi permintaan khusus dari para tamu jika memungkinkan.

Selain kekuatan tersebut diatas, terdapat kekurangan yaitu Penginapan Remaja belum menjalin komunikasi yang berkelanjutan dengan tamu yang pernah menginap sebagai bentuk perhatian dan agar tamu selalu mengingat akan Penginapan Remaja, misalnya dengan mengirim Short Message Service (SMS) pada saat hari ulang tahun tamu tersebut atau pada saat ada acara/event yang diselenggarakan oleh Dinas Kebudayaan dan Pariwisata Provinsi Jawa Timur kemungkinan tamu yang pernah menginap tersebut bisa hadir di acara/event tersebut dan menginap lagi di Penginapan Remaja.

3. Mengidentifikasi biaya dan mengalokasi-kan pada aktivitas nilai

Penginapan Remaja senantiasa berupaya untuk meraih pertumbuhan yang berkelanjutan dan memaksimumkan pencapaian target yang ditentukan pemerintah Provinsi Jawa Timur dengan mempertimbangkan tingkat resiko yang dapat diterima. Menurut hasil wawancara dengan Kepala Dinas Kebudayaan dan Pariwisata Provinsi Jawa Timur yang dalam hal ini diwakili oleh Kasubag Tata Usaha dan Kepegawaian, dan dengan Plt. Ketua Koordinator Petugas Penginapan Remaja Dinas Kebudayaan dan Pariwisata Provinsi Jawa Timur bahwa diproyeksikan tamu yang menginap di Penginapan Remaja akan mengalami kenaikan karena dipicu salah satunya faktor banyaknya even-even atau lomba-lomba khususnya di Surabaya yang bertujuan menggali potensi dan meningkatkan kreatifitas para pemuda dengan peserta baik dari luar kota Surabaya maupun luar Provinsi Jawa Timur, baik secara rombongan maupun perorangan sehingga membutuhkan tempat menginap bagi peserta tersebut dengan harga yang terjangkau, lokasi yang dekat dengan pertokoan, perkantoran dan tempat wisata serta kebersihan penginapan yang selalu terjaga.

Untuk menghadapi peluang tersebut di atas, maka diperlukan identifikasi aktivitasaktivitas yang berpotensi menjadi sumber keunggulan biaya ataupun yang memberikan value lebih dibandingkan pesaing dengan melakukan kajian atas beberapa aktivitas primer yang berpotensi menjadi keunggulan bersaing.

Pada tahap ini dilakukan identifikasi biaya dengan menganalisis rincian biaya yang kemudian dialokasikan ke dalam aktivitas value chain Penginapan Remaja.

a.Penetapan biaya pada aktivitas nilai

Rincian biaya yang telah dialokasikan dapat teridentifikasi biaya-biaya yang dikonsumsi oleh tiap aktivitas nilai Penginapan Remaja. Alokasi biaya tiap aktivitas value chain pada aktivitas primer yang berpotensi menjadi sumber keunggulan Published by University of Airlangga.

This is an open access article under the CC BY SA license (https://creativecommons.org/licenses/by-sa/4.0/) 
bersaing terlihat pada tabel 5.3. Dari alokasi biaya aktivitas primer terutama pada aktivitas logistik dalam dapat diketahui aktivitas-aktivatas yang mengkonsumsi biaya besar.

Tabel 4

Biaya Yang Berpotensi Menjadi Sumber Keunggulan Bersaing

\begin{tabular}{ll}
\hline NO. & \multicolumn{1}{c}{ JENIS BIAYA } \\
\hline 1. & Pengadaan Sabun Mandi \\
2. & Pengadaan Sikat Gigi \\
3. & Pengadaan Pasta Gigi \\
4. & Pengadaan Handuk \\
\hline \multicolumn{2}{c}{ Sumber : Data Diolah (20XX) }
\end{tabular}

b.Mengidentifikasi cost driver

Identifikasi faktor-faktor pemicu dan keterkaitan biaya adalah hal utama yang dilakukan dalam tahap ini. Dengan mengetahui pemicu dan keterkaitan biaya dari suatu aktivitas akan dapat menciptakan peluang bagi penurunan baiya. Faktor cost driver Penginapan Remaja hanya terdapat pada aktivitas primer pada logistik dalam, merupakan unit aktivitas-aktivitas yang diantara-nya meliputi :

- Pengadaan sabun mandi, sikat gigi, pasta gigi dan handuk dengan pemicu biaya jumlah pemesanan

- Pemakaian sabun mandi, sikat gigi, pasta gigi dan handuk dengan pemicu biaya jumlah hari pemakaian kamar/tingkat hunian kamar

Penyebab tingginya logistik dalam diatas dikarenakan pemilihan tempat pembelian dari logistik dalam tersebut.

Sedangkan aktivitas primer lainnya tidak teridentifikasi cost driver-nya.

- Operasi

Tarif kamar, pembenahan dan pemeliharaan serta pengembangan fisik gedung secara rutin dan jangka panjang direalisasi dengan dana rutin dan dana proyek APBD sudah ditentukan oleh pemerintah dalam hal ini Gubernur Jawa Timur yang disahkan oleh DPRD Provinsi Jawa Timur

- Pemasaran dan Penjualan

Mengikuti kegiatan dan anggaran yang ada di Dinas Kebudayaan dan Pariwisata Provinsi Jawa Timur di setiap tahunnya.

- Pelayanan Purna Jual

Dalam meningkatkan dan mem-pertahankan nilai produk semua karyawan/karyawati secara berkala dilatih kemampuan dan pengetahuan terkait standar pelayanan. Kegiatan tersebut masuk dalam anggaran Dinas Kebudayaan dan Pariwisata Provinsi Jawa Timur yang disahkan oleh DPRD Provinsi Jawa Timur. 


\section{Ratna Cristiana Dewi}

Karyawan/karyawati Penginapan Remaja yang juga sebagai Pegawai Negeri Sipil, maka untuk gaji diatur dalam Peraturan Pemerintah.

\section{Mengembangkan Competitive Advantage}

Berdasarkan hasil analisis aktivitas bernilai tambah dan aktivitas tidak bernilai tambah tersebut dapat diketahui sumber-sumber potensi competitive advantage atau keunggulan bersaing yang dimiliki Penginapan Remaja Dinas Kebudayaan dan Pariwisata Provinsi Jawa Timur, terutama dihasilkan oleh cost drivers atau penggerak-penggerak biaya yang terdapat dalam value chain pada aktivitas-aktivitas primer penginapan. Kekuatan-kekuatan yang dimiliki Penginapan Remaja adalah pada keunggulan biaya. Aktivitas-aktivitas logistik dalam, operasi, pemasaran dan penjualan, dan pelayanan memberikan konsekuensi kepada pengurangan biaya melalui efisiensi, peningkatan kinerja, pengawasan dan pengendalian yang ketat. Pada Penginapan Remaja terutama terdapat pada aktivitas-aktivitas logistik dalam yang menunjang penerapan strateginya.

Dalam lingkungan bisnis selalu ada perubahan, secara langsung peran manajamen biaya juga ikut mengalami perubahan. Hal ini juga terjadi pada Penginapan Remaja sebagai salah satu jasa akomodasi, perubahan teknologi informasi, tuntutan yang lebih baik dalam pemberian pelayanan kepada para tamu dan perubahanperubahan lain yang mengharuskan Penginapan Remaja perlu mengembangkan system informasi yang stratejik guna mempertahankan secara efektif keunggulan bersaingnya. Hal ni berarti manajemen biaya harus menyediakan informasi yang sesuai dimana sebelumnya belum disediakan oleh sistem akuntansi biaya tradisional.

Menurut pihak Penginapan Remaja, strategi bersaing yang sejauh ini dipahami sebagai strategi cost leadership/biaya rendah sudah tepat. Penekanan pada strategi cost leadership ini sebaiknya juga harus senantiasa dibarengi dengan upaya mendeteksi perubahan misalnya yang dibutuhkan para tamu yang menginap dan usaha-usaha yang dilakukan pesaing untuk membedakan produknya serta selalu mencari cara untuk meningkatkan nilai dari aktivitas-aktivitas yang dihasilkan melalui kualitas kamar yang nyaman, jasa pelayanan yang responsif dan inovasi produk yang ditawarkan di Penginapan Remaja.

Strategy low cost menekankan pada harga yang lebih rendah dibandingkan dengan kompetitor dengan tujuan untuk menarik konsumen. Dalam industri jasa akomodasi untuk bisa bersaing tidak hanya dengan menawarkan harga yang lebih rendah, melainkan juga ditunjang dengan pelayanan dan fasilitas yang memadai agar bisa meningkatkan tingkat hunian kamarnya. Konsekwensinya Penginapan Remaja harus melakukan kontrol biaya yang ketat agar harga yang lebih rendah tersebut tetap bisa memberikan pelayanan dan fasilitas yang memadai sesuai kebutuhan tamu yang menginap. 
Penginapan Remaja Dinas Kebudayaan dan Pariwisata Provinsi Jawa Timur harus berhati-hati untuk tetap memperhatikan sumber keunggulan bersaing dalam mengelola rantai nilainya terutama pada aktivitas primer penginapan sehinga dapat bernilai bagi konsumen/para tamu yang menginap.

Dalam rangka mengembangkan secara optimal keunggulan bersaingnya tersebut, Penginapan Remaja harus bisa menangkap peluang yang ada agar dapat mencapai kinerja terbaik dan memberikan manfaat serta bernilai tambah bagi pemilik dalam hal ini Pemerintah Provinsi Jawa Timur, usaha yang dilakukan dalam pengendalian biaya untuk mengembangkan keunggulannya tersebut antara lain dengan cara :

1. Membuat perencanaan kebutuhan logistik dalam terutama sabun mandi, sikat gigi, pasta gigi dan handuk untuk jangka panjang sesuai pemenuhan kebutuhan penginapan.

2. Melakukan kontrak terkait pengadaan sabun mandi, sikat gigi, pasta gigi dan handuk dalam jangka panjang dengan supplier logistik dalam tersebut.

Berdasarkan jumlah hari hunian pada tahun 20XX sejumlah 1.096, kebutuhan untuk logistik dalam terutama sabun mandi, sikat gigi, pasta gigi dan handuk maka setelah menggunakan analisis value chain dapat diketahui penurunan biayanya. Setiap kamar disediakan masing-masing 2 buah untuk kebutuhan logistik dalam bagi tamu yang menginap. Sedangkan untuk jumlah pengadaan logistik dalam penginapan selama 1 tahun ditambah $10 \%-15 \%$ dari jumlah hari pemakaian kamar selama 1 tahun sesuai kenaikan tingkat hunian kamar yang rata-rata setiap tahunnya Penginapan Remaja sekitar $10 \%$ - 15\%. Sehubungan penyediaan logistik dalam tersebut diatas pembeliannya di supermarket, maka harganya lebih mahal jika dibandingkan mengadakan kontrak dengan pihak supplier yang menyediakan perlengkapan tersebut. Perhitungan penyediaan logistik dalam sebelum dan sesudah analisis value chain sebagai peningkatan competitive advantage Penginapan Remaja Jawa Timur.

\section{CONCLUSION}

Berdasarkan pengamatan, wawancara di lapangan dan menganalisis dokumen yang ada serta pengolahan dan pembahasan hasil penelitian yang berkaitan dengan permasalahan tentang proses analisis value chain dalam upaya peningkatan competitive advantage guna mendukung penerapan strategi cost leadership pada Penginapan Remaja, maka dapat diambil beberapa simpulan dan saran sebagai berikut :

1. Penginapan Remaja Dinas Kebudayaan dan Pariwisata Provinsi Jawa Timur sebagai salah satu industri akomodasi milik pemerintah Provinsi Jawa Timur telah menetapkan cost leadership sebagai strategi bersaingnya. 


\section{Ratna Cristiana Dewi}

2. Penginapan Remaja Dinas Kebudayaan dan Pariwisata Provinsi Jawa Timur telah menganalisis value chain terutama pada aktivitas primernya sebagai upaya peningkatan competitive advantage atau keunggulan bersaing dalam rangka mendukung penerapan strategi cost leadership.

3. Analisis value chain pada aktivitas primer khususnya logistik dalam Penginapan Remaja Dinas Kebudayaan dan Pariwisata Provinsi Jawa Timur menghasilkan potensi peningkatan penghematan biaya sebagaimana dalam pembahasan penelitian.

Saran yang dapat disampaikan berdasarkan temuan dalam penelitian ini antara lain :

1. Penekanan pada strategi cost leadership ini sebaiknya juga senantiasa diikuti dengan upaya untuk mendeteksi perubahan dari kebutuhan para tamu dan usaha-usaha yang dilakukan pesaing untuk membedakan produknya, serta selalu berusaha untuk mencari cara untuk meningkatkan nilai dari produk yang ditawarkan dapat dilakukan melalui penyediaan kebutuhan sesuai keingingan konsumen dalam batas-batas tertentu, jasa pelayanan yang responsif dan inovasi produk.

2. Penginapan Remaja selain melakukan kajian dan mengidentifikasi sumber keunggulan bersaing melalui proses aktivitas-aktivitas dalam rantai nilai pada aktivitas primer, sebaiknya juga melakukan pada aktivitas pendukungnya.

3. Meskipun sudah memiliki keunggulan biaya, pihak Pemerintah Provinsi Jawa Timur dalam hal ini Dinas Kebudayaan dan Pariwisata Provinsi Jawa Timur selaku pengelola Penginapan Remaja hendaknya juga memperhatikan banyaknya pembangunan jasa akomodasi baru yang menyebabkan persaingan semakin ketat antar akomodasi sehingga dibutuhkan pemimpin penginapan yang kreatif dan inovatif serta karyawankaryawan yang produktif dan bersedia bekerja keras demi peningkatan keunggulan bersaing dengan penginapan yang lain, karena hanya penginapan yang memiliki keunggulan bersaing/competitive advantage yang akan dapat memenangkan persaingan. competitive advantage suatu penginapan dapat diperoleh jika berorientasi pasar, berorientasi pembelajaran dan mampu mengelola dengan baik.

4. Penyediaan logistik dalam khususnya pengadaan sabun mandi, sikat gigi, pasta gigi dan handuk melalui kontrak dengan pihak supplier perlengkapan tersebut dapat diperoleh penurunan biaya yang cukup signifikan. Dari penurunan biaya tersebut sebaiknya dapat digunakan untuk peningkatan pelayanan bagi tamu yang menginap, misalnya dengan mengirim Short Message Service (SMS) pada saat hari ulang tahun tamu tersebut atau pada saat ada acara/event yang diselenggarakan oleh Dinas Kebudayaan dan Pariwisata Provinsi Jawa Timur barangkali tamu yang pernah menginap tersebut bisa hadir di acara/event tersebut dan menginap lagi di Penginapan Remaja.

Published by University of Airlangga.

This is an open access article under the CC BY SA license (https://creativecommons.org/licenses/by-sa/4.0/) 


\section{REFERENCES}

Barney, J.B. 1995. Looking Inside for Competitive Advantage. Academy of Management Executive Vol. 9 No. 4

Berita Resmi Statistik No. 10/02/Th. XVI, 1 Februari 2012

Biro Pusat Statistik. 2012. Jumlah Kunjungan Wisatawan Manca Negara Berdasarkan Wilayah: Jakarta.

Bungin, M.B. 2011. Penelitian Kualitatif: Komunikasi, Ekonomi, Kebijakan Publik, dan IImu Sosial Lainnya. Jakarta: Kencana

Dinas Kebudayaan dan Pariwisata Kota Surabaya. Laporan Jumlah Tamu Wisman Wisnus Yang Menginap di Hotel, Pondok Wisata dan Penginapan di Kota Surabaya 2010 - 2013. Surabaya

Dinas Kebudayaan dan Pariwisata Provinsi Jawa Timur. Pariwisata Jawa Timur Dalam Angka 2012. Surabaya

Donelan, Joseph G., Kaplan, Edward A. 2000. Value Chain Analysis: A Strategic Approach to Cost Management. Thomson Leearning

Fitri, H. 2010. Analisis Strategi Bersaing Telkom Dalam Industri Internet. Tesis Fakultas Ekonomika Dan Bisnis Program Studi Magister Manajemen. Universitas Gajah Mada, Yogyakarta

Hansen, Don R., and Maryanne M. Mowen. 2000. Managerial Accounting: Akuntansi dan Pengendalian. Alih Bahasa Tim Salemba Empat. Salemba Empat Jakarta

Harun. 2005. Kelembagaan Dinas Pariwisata Provinsi Jawa Timur : Studi Tentang Model Pengembangan Kelembagaaan di Dinas Pariwisata Provinsi Jawa Timur. Disertasi Program Doktor Ilmu Administrasi, Surabaya: Untag

Henni, R. 2009. Analisis Strategi Bersaing Dalam Meningkatkan Posisi Perusahaan (Studi Kasus Pada PT. Sun Dewata Express Cabang Medan). Tesis Fakultas Ekonomi Universitas Sumatera Utara, Medan

Porter, Michael E. 2001. Competitive Strategy. Free Press. New York

Porter, Michael E. 1985. Competitive Advantae; Creating and Sustaining Superior Performance. Free Press. New York

Republik Indonesia, 2009, Undang-Undang Nomor 10 Tentang Kepariwisataan.

Shank, John K., and Vijay Govindarajan. 1995. Strategic Cost Management and The Value Chain. South Websier Publishing and Warren Gorham Lamont

Shank, John K., and Vijay Govindarajan.1993. Strategic Cost Management The New Tool for Competitive Advantage. South Websier Publishing and Warren Gorham Lamont

Sulistijowati, R. 2012. Analisis Value Chain Pada Aktivitas Primer Dengan Penerapan Strategi Cost Leasership Sebagai Upaya Peningkatan Keunggulan Bersaing (Studi Kasus Pada PT. Semen Gresik). Tesis Program Studi Magister Akuntansi Fakultas Ekonomi dan Bisnis Universitas Airlangga, Surabaya

Weiler, Jhon, Schemel, Nelson. 2003. Value Chain and Value Coalitions. ICH White Paper Yin, Robert K. 2012. Studi Kasus: Desain \& Metode. PT Rajagrafindo Persada. Jakarta 